\title{
Organization of the Statutory Audit of Financial Statements in Romania
}

\author{
Gabriela-Felicia Ungureanu, The Bucharest Academy of Economic Studies, Romania
}

\begin{abstract}
Economic entities around the world, regardless of their membership - public or private sector - the size, the object of activity, prepare financial statements for presentation of financial information users (investors, creditors, customers, suppliers, public institutions). The financial statements provide information about financial position, performance and changes in financial position of an entity information underlying to base decision process. For Romania, the financial audit was not a tradition. Recognized as a top area of the accounting profession, financial audit was legislated in 1999. Statutory audit, audit of annual financial statements or consolidated annual statements have been established 9 years later (Emergency Regulation no. 90 June 24, 2008), by transposing Directive 2006/43/EC of 17 May 2006 of the European Parliament and of Council on statutory audit of annual accounts and consolidated accounts, in order to ensure oversight of auditors, in the public interest.
\end{abstract}

\section{Cuvinte cheie}

statutory audit, financial statements, decisions, management, public interest entities, "International Standards on Auditing.

JEL Code: M42

\section{Introduction}

For Romania, the financial audit was not a tradition. Statutory audit was governed relatively late, by Emergency Regulation no. 90 June 24, 2008, in order to transpose Directive 2006/43/EC of 17 May 2006 of the European Parliament and of the Council on statutory audit of annual accounts and consolidated accounts.

The audit is the professional examination by an independent and competent persson the fidelity representations and financial accounting in order to express an opinion by reference to a criterion. Audit activities include the one hand, examining on a test basis of the evidence about disclosure of financial statements and the second hand - evaluating the appropriateness and application of accounting principles used and financial controls arranged and conducted by management to increase the effectiveness of the entity.

Statutory audit is given to all audit activities on individual or consolidated annual financial statements as required by Community legislation transposed into national legislation. Individual statutory auditor is approved in accordance with the provisions of Emergency Regulations no. 90/2008 updated by the competent authority respectively Chamber of Financial Auditors of Romania (CFAR), to carry out statutory audit. In meaning of the Emergency Regulations no. 90/2008, approval of a statutory auditor or audit firm means approval

Statutory audit work is carried out only by statutory auditors or audit firms were subject to authorization, which approval under the terms of order Emergency Regulations no. 90/2008 updated.

The competent authority responsible for approving statutory auditors and audit firms is the Chamber of Auditors of Romania. Final responsibility for approving statutory auditors and audit firms is public oversight body. 


\section{Objectives of Research}

- implementation of Directive 2006/43/EC of May 172006 of the European Parliament and the Council on statutory audit of annual accounts and consolidated accounts statutory audit to ensure compliance with the requirements of European directives in Romania;

- development of a harmonized approach to statutory audit at EU level;

- achievement of a system of public oversight for statutory auditors and audit firms, based on European principles to ensure monitoring of audit work in Romania.

\section{Research Methodology Includes Following Stages}

- study of legislative rules;

- knowledge on statutory audit and analysis of information;

- how was the transposition of Directive 2006/43/EC on statutory audit;

- parallels between national and European requirements;

- regulation legal framework for audit activities;

- Council for the establishment of public oversight in order to ensure the supervision (in public) the auditors;

- to update the national legislation as required by EU legislation.

\section{Expected Results}

- investors regain confidence in individual financial statements and consolidated by strengthening the profession;

- ensure sound financial management based on optimal decision, following a statutory audit quality.

\section{The Level of Knowledge in the Area of Auditing - Auditing the Financial Statements Required}

Audit obligation defined by national law, thus:

- Accounting Law no. 82/1991, republished specifies that the annual financial statements will be accompanied by audit reports due to financial audit by auditors, individual or legal persons authorized under the law;

- Minister of Public Finance Order no. 3.055/2009 for approving accounting regulations consistent with European directives, requires that annual financial statements prepared by public interest legal persons subject to statutory audit;

- Law no. 297/2004 updated, on the capital markets specifies that financial statements and those of transactions set out in the annual report of entities subject to licensing, supervision and control of the National Securities Commission (NSC) must be audited by financial auditors;

- Order no. 1 / 2010 of the Insurance Supervisory Commission for approval of the Norms about of the end of the 2009 financial year for insurance companies provides that the annual financial statements of insurers and reinsurers will be audited by statutory auditors, legal persons authorized under law.

The legal framework:

- Emergency Regulations no. 75/1999 republished and updated on the financial audit activity, with amendments and additions, which are the basis for organizing the financial auditing and regulating the exercise of independent financial auditor profession;

- Regulation of organization and operation of the Chamber of Auditors Financial in Romania, approved by GD no. 983/2004, as amended and supplemented; 
- Emergency Regulation no. 90/2008 updated on statutory audit of annual accounts and consolidated annual financial statements, which transposes Directive 2006/43/EC of the European Parliament and the Council on statutory audit of annual accounts and consolidated accounts

\section{Statutory Audit}

Economic entities around the world, regardless of their membership - public or private sector - the size, the of object of activity - prepare financial statements for presentation of financial information users (investors, creditors, customers, suppliers, institutions public).

The financial statements provide information about financial position, performance and changes in financial position of an entity - information underlying to base of the decision process. It is important that managers know what information is needed, how to obtain such information in regularly and systematically way and how to integrate information in making decisions.

For managers it is important to observe the economic environment in which evolves entity, to study the internal organization and how operating its various services, analyzing strengths and weaknesses, opportunities and threats entity. Each manager has available a set of methods which will assist in making decisions and financial reports is one of them.

To give greater confidence to users of financial reports and greater credibility of the annual accounts, we were asked to audit the financial statements, the person authorized, independent and competent to carry out statutory audits in accordance with International Standards on Auditing.

\section{Transposition of Directive 2006/43/EC}

To Romania, financial audit was not a tradition. Recognized as a top area of the accounting profession, financial audit was legislated in 1999. Statutory audit, audit of annual financial statements or consolidated annual statements have been established 9 years later (Emergency Regulation no. 90 June 24, 2008), by transposing Directive 2006/43/EC of 17 May 2006 of the European Parliament and of Council on statutory audit of annual accounts and consolidated accounts, in order to ensure oversight of auditors, the public interest. "This ordinance establish throught the rules how to avoid any doubts on any interpretation of the authority and responsibilities of the Chamber of Auditors (CFAR), as a professional body invested by the legislature to organize, coordinate and authorization to that end in Romania ", said Univ. Ph. D. Ion Mihailescu, President CAFR - for "Financiar", on October 29, 2008. Since entered into force Ordinance 90/2008, all references of "financial audit" of existing in previous legislation will actually make reference to statutory audit.

\section{Parallels Between National and European Requirements}

Key provisions covered both of the Emergency Regulation 90/2008 and Directive 2006/43/EC relating to:

- designation of competent authorities responsible for regulating and / or public oversight of statutory auditors and audit firms or their specific issues;

- key audit partners and statutory auditors appointed by the audit firm to perform the mission or statutory auditors signing the audit report;

- set conditions of approval the statutory auditors and audit firms;

- statutory audit activity by statutory auditors or audit firms, which have been subject to authorization ;

- theoretical knowledge and professional ethics; 
- the requirements of independence, objectivity and confidentiality relating to statutory auditors;

- developing "Electronic Public Register to registration of statutory auditors;

- application of the auditing standards and audit reporting;

- statutory responsibility of the audit work consolidated annual financial statements (statutory audits of the consolidated accounts);

- criteria to be met by quality assurance systems;

- setting up of system of investigations and penalties;

- establish an audit committee in each public interest entities;

- organizing public oversight systems of statutory audit.

\section{Statutory Audit Activities}

Basic elements of the concept of statutory audit are:

- the professional auditor - competence and independence, which is part of / or not from an independent body;

- legality - statutory audit is governed by the International Auditing Standards, Directive 2006 / 43/CE and national legislation;

- the entity's financial statements which are the object of the checks;

- expressing an opinion (based on audit evidence) on the fair presentation, clear and complete financial position, results of the entity;

- quality criteria by which to make the examination and expressed the view (auditing standards).

The objective of statutory audit:

Auditul statutar este un audit extern având drept obiectiv examinarea profesională a informațiilor financiare cu scopul de a exprima o opinie responsabilă şi independentă cu privire la situațiile financiare, dacă acestea sunt întocmite, sub toate aspectele semnificative, în conformitate cu reglementările de raportare financiară.

Statutory audit is an external audit whose objective is to verify the financial information in order to express a responsible and independent opinion on the financial statements if they are prepared, in all material respects, in accordance with the financial reporting. Financial audit has specific characteristics, is an essential element to increase the credibility of financial reporting, which involves a high degree of interest from the public.

Scope:

The auditor makes audit activities in accordance with International Standards on Auditing ( ISA) and have full responsibility for the audit report in connection with the annual consolidated financial statements. Where, in conducting the audit, statutory auditors have applied a different standard is appropriate in the audit report to make reference to it. Procedures audit, to conduct an audit in accordance with International Standards on Audit shall be determined by the auditor in compliance with each audit, based on his professional judgement. The statutory auditor or audit firm is appointed by the general meeting of shareholders of audited entity.

Conditions for implementation audit of statutory

Audit activities are carried out only by statutory auditors or audit firms were subject to authorization, as that approval under Emergency Regulation nr.90/2008. Authorization assures the compatibility with internal market rules and audit firms already incorporated in the market. The competent authority responsible for approving statutory auditors and audit firms is the Chamber of Auditors of Romania, which, in this sense develop procedures and rules. Ultimate responsibility for approving statutory auditors and audit firms is oversight body. To be authorized statutory auditors and audit firms must meet the cumulative number of statutory requirements on the structure and audit process as: 
- good reputation, in the sense of the provisions of the code of ethics adopted by the Ethics Committee of the International Federation of Accountants - compromising its, it is a cause for withdrawal of approval;

- higher education in the economic field, completion of specialized training, conducting training courses practice and passed an examination of professional competence;

- be concerned with continuous improvement training, to possess knowledge of tax laws, social insurance and in the field of international auditing standards;

- to agree on the inclusion in the electronic public register - this register allows interested parties to determine whether an audit firm (or auditor) has been approved and provides statutory details of those enrolled. Register of statutory auditors shall be published in the Official Journal of Romania and is available in electronic format on the Chamber website. Responsible for drawing up, updating and publication of public register is the Chamber, under monitoring oversight body.

- be independent of the audited entity - auditors and/or statutory audit firms should not be involved in decision-making and management of the audited entity or accept commitments that would compromise independence. Auditors should document any significant threat to their independence;

- to be the subject to verification audit quality - quality audit system is implemented by the Chamber. Quality assurance involves evaluating the requirements of independence and integrity of the fees collected the volume of resources expended, compliance with applicable auditing standards and quality control systems of audit firm.

Quality assurance checks are made at regular intervals, which is not more than 6 years, 3 years respectively, for public interest entities.

Oversight body, together with the Chamber, shall ensure that all statutory auditors and audit firms respect the principles of professional ethics, which deals at least in their operation in the public interest and requirements on independence and objectivity, as defined in the Code of Ethics. Board may prescribe by regulation situations that could jeopardize the independence and objectivity of the statutory auditors or audit firms.

- confirm annually in writing, their independence from the audited public interest entity;

- notify the audit committee, additional services provided to the auditee;

- ensure confidentiality and documents which have had access. A statutory auditor or audit firm that has ended to be employed in an audit mission is still subject to the provisions on confidentiality and professional secrecy. Statutory auditor and audit firm, and employees of audit firms must treat as confidential any information about their knowledge during their work, unless the laws or regulations provide otherwise.

Systems of investigation and sanctioning contraventions

The oversight body set up systems of investigations and sanctions to detect correct and prevent improper conduct of statutory audit. Apply sanctions to be effective, proportionate and dissuasive about statutory auditors and audit firms, where statutory audits are not conducted in accordance with this Emergency Regulation. Audit firms respond, by law, in their capacity as members of the Chamber, where one of the partners, directors or employees, with no quality auditor statutory intervene in the independent profession of statutory auditor in order to prejudice the independence of statutory auditors carrying out this activity on behalf of the audit firm.

Audit Committee

Every public entity must have an audit committee. Membership of audit committees is determined by the regulators of public interest entities in accordance with the laws in force, but at least one member of the audit committee is independent and has expertise in accounting and/or audit. The Audit Committee is responsible for monitoring the process financial reporting, effectiveness of internal control systems, internal audit and risk management within the entity. It also monitors individual statutory audit of consolidated financial statements, checks and monitors the independence of the statutory auditor or audit firm and, in particular, additional services audited entity. 
For public interest entities, a proposal from the administrative or supervisory body on the appointment of a statutory auditor or audit firm is based on a recommendation of the Audit Committee. The statutory auditor or audit firm report on the audit committee key issues arising from statutory audit and in particular on material weaknesses in internal control regarding financial reporting process.

\section{Public Oversight Board for Auditing Statutory}

Emergency Regulations no. 90/2008 sets out the objectives of Council as:

- public oversight of statutory audit work;

- drawing up a strategy on public oversight of statutory audit work;

- monitoring and coordination of implementation of International Standards on Auditing and

Code Ethics;

- promote increased public confidence in statutory audit work;

- development of cooperation and communication with international bodies in the field of ISA;

- Romania's representation, with professional organizations, international bodies related to ISA, the statutory audit and supervision of public participation specialized staff in meetings of these bodies;

- developing proposals to the Government on amending and supplementing the Regulation on organization and operation of the Council;

- transmission of information and answers to requests from the European Commission regarding the statutory audit profession and supervision national public statutory audit activity.

The Council, through its specialized departments established by internal rules of organization and operation, has the following duties:

- monitored in accordance with annual plan established quality control of statutory audit;

- monitors the national legal framework corresponding measures taken at the European

Commission on the independence of statutory auditors;

- fullfils agreements with corresponding bodies in the Member States of the European Union in public oversight of statutory audit work;

- provides information on public institutions public oversight of statutory audit work and information on adoption and implementation of ISA;

- improves the general directions and methods approved by the regular inspections carried out under these schemes and ensure their proper implementation by the Chamber of Financial Auditors of Romania, according to the requirements for quality management systems audit work;

- take measures for the proper conduct of inspections and their intended results;

- monitors the Chamber activity on the authorization of statutory auditors and audit firms and on the public register;

- endorse the rules and regulations developed by the Chamber of statutory audit work;

- issue rules and regulations with respect to the public oversight of statutory audit work, as specified in internal rules of organization and functioning of the Council;

- conduct their own investigations on statutory auditors and audit firms and adopt appropriate measures following findings;

- review the annual report prepared and submitted by the Chamber, on the work of quality control and where appropriate, impose measures;

- it monitors the training of statutory auditors.

The Council is lead by a Board of Governors, are appointed representatives of institutions with regulatory responsibilities in accounting, namely the Ministry of Public Finance, National Bank of Romania, the National Securities Commission Insurance Supervisory Commission of Supervision Private Pension System, Ministry of Justice, the professional auditing bodies and representatives of academic profile and the business environment in 
Romania. Of note, the public oversight system is governed by non-practitioners who have expertise in areas relevant to statutory audit.

\section{Conclusions}

Ordinance introduced strict rules, national, on accede to the profession (trainees must have a length of activity accounts for less than 4 years), about the independence and integrity of the statutory auditor and / or audit firm (introducing the requirement that the key partners responsible for audits to be changed at an interval of seven years), on quality assurance (quality assurance should be performed at least once every 3 years), etc...

However, Emergency Regulations no. 90/2008 transposed the provisions of $8{ }^{\text {th }}$ Directive of European Union providing the necessary legal basis Romanian auditors to contribute to the integrity of financial markets by transparent and quality reporting, which helps investors to know and understand the companies in which they invest. Standards, regulations and monitoring activities ensure the public that financial markets can operate in an efficient and ethical. Regaining public confidence in the annual accounts and consolidated annual financial statements published by companies on capital markets is important - it represents in fact the real challenge of the moment. Achieving this goal can be done by ensuring quality statutory audit of financial statements to give the public a sound basis in economic decision making. This is evident at national level, public oversight role of monitoring and coordination of implementation of International Standards on Auditing (ISA) and the Code of Ethics, by statutory auditors and audit firms, they becoming the supreme guarantor of the application best practices for statutory audit profession.

\section{Bibliography}

1. Government Emergency Regulation no. 90/2008 updated, on the statutory audit of annual accounts and consolidated annual financial statements;

2. Directive 2006/43/EC of the European Parliament and of the Council, on statutory audits of annul accounts and consolidated accounts - Official Journal of the EU;

3. Government Emergency Regulation no. 75/1999 republished, on financial audit activity;

4. Accounting Law no. 82/1991 republished;

5. Law no. 297/2004 updated on the capital market;

6. OMEFP no. 3.055/2009 approval Accounting Regulations in accordance with European directives;

7. Law no. $672 / 2002$ updated, on public internal audit;

8. Government Decision no. 88/2007 for approving internal audit standards;

9. International Audit Standards- Publisher House IRECSON, 2007:

$\checkmark \quad$ ISA 200 - Main Objectives and General Principles to Govern Audit;

$\checkmark \quad$ ISA 240 - The Auditor's Responsibility in Analyzing Frauds as Part of Financial Statements Audit;

$\checkmark \quad$ ISA 315 - Knowing the Entity and the environment. The Evaluation of Significant Misstatements; 